\title{
Heavy poaching in prime habitat: the conservation status of the West Indian manatee in Nicaragua
}

Ignacio Jiménez

\begin{abstract}
This study provides an overview of the conservation status of the West Indian manatee Trichechus manatus in Nicaragua, including data on habitat availability, manatee distribution and relative abundance, and current threats. The data is based on surveys from boats and extensive interviews with local people. Nicaragua harbors one of the largest areas of habitat suitable for manatees in Central America. The species has an almost continuous distribution along the country's eastern, Caribbean coast and inland in some watercourses. There are larger groups of manatees in brackish lagoons than in freshwater rivers. Seasonal migrations and lengthy daily travels influenced by tides have been reported. The main threats to these manatees include poaching and incidental drowning in fishing nets, while boat traffic,
\end{abstract}

pollution and habitat loss presently seem to be negligible factors in Nicaragua. Poaching is widespread along the coast and it is estimated that c. 40 manatees are killed annually throughout the country. Enforcement of hunting laws and protected areas is almost non-existent, with the exception of the Southeastern Nicaragua Biosphere Reserve. This may explain why manatees have disappeared from a few areas and become rare in others. Unless restrictions are imposed on poaching and on the use of gill nets within inland wetlands, the West Indian manatee may become rare throughout Nicaragua in the near future.

Keywords Hunting, marine mammal, Nicaragua, poaching, Trichechus manatus, West Indian manatee.

\section{Introduction}

The West Indian manatee Trichechus manatus is an aquatic, herbivorous mammal that inhabits rivers, estuaries and coastal areas close to fresh water sources (Lefebvre et al., 1989). Manatees play an important role in Caribbean folklore and traditions, may play an important role in the nutrients cycle of wetlands, and have a touristic appeal that benefits local people in remote areas (Baughman, 1946; O'Shea \& Salisbury, 1991; NRCA/ UNEP, 1994). Because of their low reproductive rate they are particularly susceptible to over-exploitation and population declines, and the species is presently catagorized as Vulnerable on the IUCN Red List according to criterion A2d, i.e. a projected reduction in the population of at least $20 \%$ within the next 10 years or three generations because of levels of exploitation (O'Shea et al., 1995; Hilton-Taylor, 2000).

Nicaragua has the most extensive coastal wetlands and lowland and mangrove forests on the eastern,

Ignacio Jiménez Programa Regional en Manejo de Vida Silvestre para Mesoamérica y el Caribe, Universidad nacional, Apdo. 1350-3000, Heredia, Costa Rica.

Present address: Especies y Espacios Internacional, Avda. Suecia 27. 7 46010, Valencia, Spain. E-mail: I_Jimenez_perez@yahoo.es

Received 19 January 2001. Revision requested 1 June 2001. Accepted 10 April 2002
Caribbean side of Central America. The limited research that has been carried out on manatees in Nicaragua has examined less than half of the species' potential range, and knowledge of the species' population status and distribution is therefore incomplete (NRCA/UNEP, 1994). O'Donnell (1981) carried out interviews and boat surveys along the San Juan River, where he reported low numbers of manatees, and he received information indicating that manatees may be present in Lake Nicaragua. Carr (1993) carried out two aerial surveys over the Miskito Coast, where he found one of the highest densities of manatees in the Caribbean. Úbeda and Weijerman (1998) assessed the conservation status of the species around Pearl Bay, and Chacón (2000) studied the distribution and conservation of manatees in Rama Cay, an Indian community inside Bluefields Bay.

The objectives of this study were to: 1) assess habitat availability for the West Indian manatee in Nicaragua, 2) determine present and historical distribution of the species in the entire country, 3) locate areas with the largest manatee groups, 4) identify and evaluate human impacts and the main threats to the species, and 5) compile available local knowledge on manatee ecology.

\section{Study area}

Eastern Nicaragua has extensive flood plains of up to $100 \mathrm{~km}$ in width that include many slow-moving rivers 
and creeks, and large brackish lagoons and bays near the coast. Shallow waters with extensive seagrass beds extend offshore (Phillips et al., 1982). Vegetation types range from humid to perhumid tropical forest, and mean annual rainfall increases from north to south, from 2,500 $\mathrm{mm}$ near the border with Honduras to $6,000 \mathrm{~mm}$ at San Juan del Norte close to the border with Costa Rica (MARENA, 1999). The combination of large floodplains and high rainfall creates a rich complex of wetlands, with a corridor of brackish to fresh water parallel to the coastline. The width of the floodplains is greater and their water salinity lower in the rainy season (May-December) than in the dry season (January-April). Freshwater rivers cross the coastal floodplain on a westeast axis. Rivers in the northern half of the country are surrounded by pine savannas, riverine forests, and mangroves. Coastal lagoons are almost completely surrounded by mangroves. In the southern region most rivers have their shores covered by rainforest or Rhapia taedigera palm swamps, and some freshwater lagoons are surrounded by grass swamps.

Human population density in estern Nicaragua is relatively low and many villages were deserted during the civil war of the 1980s. Cultural and ethnic variety is rich, with Miskito Indians living mostly in the northern half, black Caribbeans, known also as garifonas, and Afro-American creoles living in the coastal communities and towns of central Nicaragua, and a small group of Rama Indians inhabiting the southern area of Bluefields Bay and the Punta Gorda and Maíz rivers. Hispanic mestizos are the dominant ethnic group in communities inland and in the south. Of all these ethnic groups the Miskito Indians, garifonas, creoles and Rama Indians have a tradition of manatee hunting (Conzemius, 1932; Baughman, 1946; Nietschmann, 1972; Loveland, 1976; O’Donnell, 1981; Reynolds \& Odell, 1992; Jiménez, 2000). Local people live mostly off subsistence agriculture, fishing, and some hunting. Relatively pristine and quasinatural landscapes are common throughout the region due to the absence of intensive agriculture or a cattle industry and, as pesticide use is low, water quality tends to be good.

\section{Methods}

In July and August of 1998 I surveyed the southern region of Nicaragua near the border with Costa Rica (the San Juan and Indio river basins), and I surveyed the rest of the country in February and March 2000. With the use of boats I assessed habitat availability and searched for feeding signs of manatees in every major watercourse in Nicaragua where manatees could potentially occur. A river or lagoon was considered to be suitable for manatees when it had most of the following characteristics: abundant and accessible aquatic vegetation, slow currents, a width $>50 \mathrm{~m}$, average depth $>2 \mathrm{~m}$, and some surrounding forest cover. These habitat parameters have previously been identified as important for the presence of manatees in a similar tropical environment in Costa Rica (Jiménez, 1998). Manatees leave distinct signs when feeding on emergent aquatic vegetation: the signs tend to occupy a large area and have a rougher cut than those left by river turtles (the grazing cut of a manatee is similar to that of a domestic cow). When found, these signs confirm the presence of manatees. In total I surveyed $>2,000 \mathrm{~km}$ of watercourses (Fig. 1). I also carried out 14 ad-hoc silent waits in selected areas during early morning or late afternoon to try to observe manatees.

I interviewed local people living near coastal wetlands, using translators only for interviews in the Miskito language. In each village I identified key informants who were knowledgeable about the status and natural history of manatees in the area surrounding their community, and questioned them using informal in-depth interviews that covered a set of pre-designated subjects including manatee distribution, hunting techniques, observed group sizes, and manatee behaviour. To compile recent manatee sightings and hunting incidents, short interviews were also conducted with other local people. Both types of interviews provided information about past and present manatee distribution and relative abundance, existing threats and the ecology of the species. A total of 171 short and 27 in-depth interviews were carried out during the two field seasons. I also interviewed local natural resources managers and law enforcement officers (Ministry of Environment officials, police and navy officers, and members of local NGOs) to assess the status of any conservation measures or relevant laws.

\section{Results}

\section{Habitat, distribution and relative abundance}

From its northern border at Coco River to its southern tip on the San Juan River the coastal flood plains of eastern Nicaragua contain extensive habitat that is suitable for manatees (Table 1, Fig. 1), in particular the freshwater rivers and their associated small lagoons, and large brackish lagoons or bays with their associated rivers. I collected 189 reports of manatee sightings, found feeding signs at 17 sites, and saw manatees on three occasions (Table 1). This information indicates that manatees have an almost continuous distribution along the eastern coastline of Nicaragua (Fig. 1). They are known from almost every major coastal wetland and, in the San Juan, Kurinwás and Wawa rivers, have been 


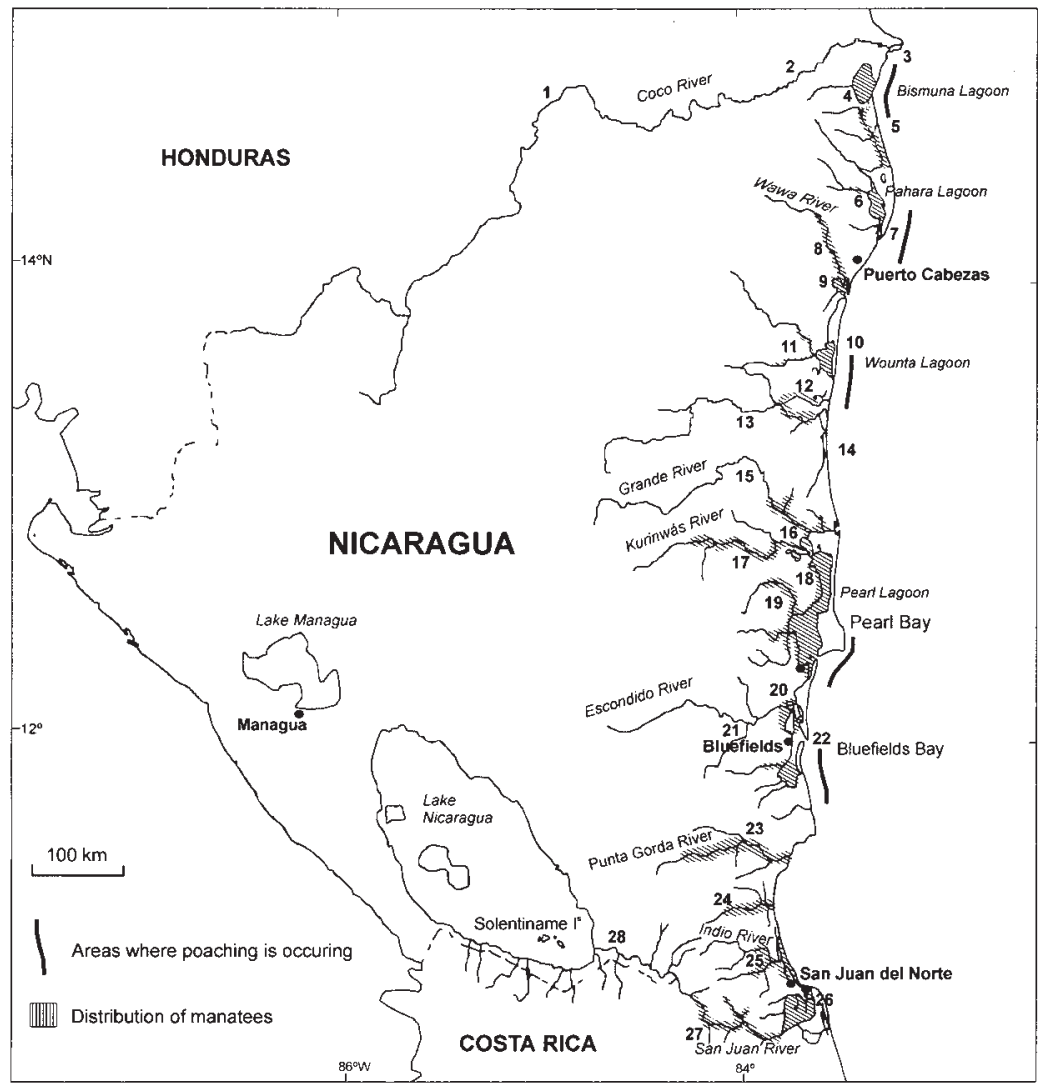

Fig. 1 Distribution of the West Indian manatee in Nicaragua, indicating areas where the species is being actively hunted. Numbers identify watercourses in Table 1. sighted $>60 \mathrm{~km}$ upstream from the river mouth, to the point where rivers become too shallow, the edges lack accessible vegetation or rapids appear. Manatees seem to be absent in Lake Nicaragua, except for reports of a single animal off the Solentiname archipelago within the lake in 1998 and 1999. Access to the lake from the river San Juan is impeded by a series of rapids that start in Machuca. The manatee reported from Solentiname might be a single individual that managed to cross the rapids on an exceptionally high flood rather than a member of a resident subpopulation.

The only watercourses with habitat suitable for manatees but no manatee sightings for several decades are the Coco River, on the border with Honduras, and Mahogany creek, a tributary of the Escondido River (Table 1, Fig. 1). Fishermen also reported manatees outside river bars and near the beach, although the existence and extent of suitable habitat in the sea is unknown. However, these reports show that there is movement of individuals through the sea between rivers and brackish lagoons, and that some animals may feed along the coast, as noted by Carr (1993).

Larger groups of manatees were reported in the large brackish lagoons of Bismuna, Wounta and Pearl Bay than in rivers (Table 1). Manatees seem to be most abundant in Bismuna and Wounta lagoons, Pearl Bay, the northern lagoons and southern tip of Bluefields Bay, the Indio river, and the low and medium tracts of the San Juan River (Fig. 1). When asked if manatees were more or less common now than in the past, 16 informants said that they used to be more common several decades ago, six stated they have always been scarce, and four reported that they are more abundant now. Comparing the present distribution with information given by longterm residents, it appears that manatees have a) disappeared from a few areas where they were seen 30 years ago (Mahogany Creek, Walpasiksa River bar and perhaps Lake Nicaragua), b) become scarce in others (Prinzapolka and Grande rivers), and c) been absent from some areas for decades (Coco River).

\section{Ecology}

During my interviews with key informants four aspects of the ecology of manatees were stated consistently. Firstly, most informants stated that manatees migrate from one large lagoon to another and from these lagoons into rivers; manatees that live around brackish lagoons tend to feed there during the winter, when the water is fresher and the banks of Syringodium bloom, and they move upstream into nearby rivers in search of freshwater or emergent vegetation during the dry season. 
Table 1 Habitat suitability for manatees and most abundant vegetation type, number of interviews with local inhabitants, consistent reports of manatee sightings and largest reported group size, presence of feeding signs observed during the surveys, number of manatee sightings during the surveys, estimated number of manatees killed from January 1999 to 2000 and method used, and estimated number of active hunters and age of hunters in the 28 watercourses surveyed in Nicaragua.

\begin{tabular}{|c|c|c|c|c|c|c|c|}
\hline Watercourse ${ }^{a}$ & $\begin{array}{l}\text { Habitat suitability/ } \\
\text { most abundant } \\
\text { vegetation }^{\mathrm{b}}\end{array}$ & $\begin{array}{l}\text { No. } \\
\text { interviews }\end{array}$ & $\begin{array}{l}\text { Sighting } \\
\text { reports/ } \\
\text { largest } \\
\text { group size }^{c}\end{array}$ & $\begin{array}{l}\text { Feeding } \\
\text { signs }^{c}\end{array}$ & Sightings & $\begin{array}{l}\text { No. manatees } \\
\text { killed (1999-2000)/ } \\
\text { method used }^{\mathrm{d}}\end{array}$ & $\begin{array}{l}\text { No. active } \\
\text { hunters / } \\
\text { average age }\end{array}$ \\
\hline 1. Higher Coco River & Too rapid & 17 & No & No & 0 & 0 & \\
\hline 2. Lower Coco River & Excellent/FG & 5 & No & No & 0 & 0 & \\
\hline 3. Gracias a Dios Lagoon & Too shallow & 3 & No & No & 0 & 0 & \\
\hline 4. Bismuna Lagoon & Excellent/M \& SG & 8 & Yes $/ 20$ & No & 0 & $8-10 / \mathrm{H}, \mathrm{GN}$ & $5-8 / 50-60$ \\
\hline 5. Sandy Bay & Excellent/M \& SG & 15 & Yes/3 & No & 0 & 0 & \\
\hline 6. Pahara Lagoon & Excellent/M \& SG & 4 & Yes/1 & No & 0 & 0 & \\
\hline 7. Krukira Lagoon & Excellent/M \& SG & 8 & Yes/3 & No & 0 & $7-9 / \mathrm{CN}$ & $6-10 / 20-40$ \\
\hline 8. Wawa River & Excellent/M \& FG & 7 & Yes/7 & No & 2 & 1 & \\
\hline 9. Karatá Lagoon & Excellent/M \& SG & 9 & Yes /7 & No & 0 & $2 / \mathrm{GN}$ & $0-4 />60$ \\
\hline 10. Wouhnta Lagoon & Excellent/M \& SG & 16 & Yes/20 & No & 1 & $8-10 / \mathrm{H}, \mathrm{GN}$ & $>20 / 20-30$ \\
\hline 11. Layasiksa river & Good/M & 3 & Yes/1 & No & 0 & 0 & \\
\hline 12. Walpasiksa River & Excellent/M \& SG & 4 & Yes/1 & $?$ & 0 & 0 & \\
\hline 13. Prinzapolka River & Good/FG & 8 & Yes/1 & No & 0 & 0 & \\
\hline 14. Kuantwatla Lagoon & Poor & 1 & $?$ & No & 0 & 0 & \\
\hline 15. Grande River & Good/FG & 7 & Yes/2 & No & 0 & $2 / \mathrm{H}$ & $1 />60$ \\
\hline 16. Top Lock Lagoon & Excellent/SG \& FG & 3 & Yes/8 & Yes & 0 & 0 & \\
\hline 17. Kurinwás River & Excellent/FG & 3 & Yes/? & Yes & 0 & 0 & \\
\hline 18. Pearl Bay & Excellent/M \& SG & 16 & Yes/6 & No & 0 & $5-6 / \mathrm{H}, \mathrm{GN}$ & $>12 /$ not known \\
\hline 19. Wawashang river & Excellent/M \& FG & 2 & Yes/? & Yes & 0 & 0 & \\
\hline $\begin{array}{l}\text { 20. Escondido River, } \\
\text { Smokey Lane and } \\
\text { tributaries }\end{array}$ & $\begin{array}{l}\text { Excellent/ } \\
\text { M, SG, \& FG }\end{array}$ & 8 & Yes/14 & No & 0 & 0 & \\
\hline 21. Mahogany Creek & Excellent/FG & 2 & No & No & 0 & 0 & \\
\hline $\begin{array}{l}\text { 22. Bluefields Bay and } \\
\text { tributary creeks }\end{array}$ & $\begin{array}{l}\text { Excellent/ } \\
\text { M, SG, \& FG }\end{array}$ & 8 & Yes/? & Yes & 1 & $1-2 / \mathrm{H}$ & $8-10 />40$ \\
\hline 23. Punta Gorda River & Excellent/FG & 8 & Yes/1 & No & 0 & 1 & \\
\hline 24. Maíz River & Excellent/FG & 7 & Yes/? & Yes & 0 & 0 & \\
\hline 25. Indio River & Excellent/FG & 12 & Yes/2 & Yes & 0 & 0 & \\
\hline $\begin{array}{l}\text { 26. San Juan del Norte } \\
\text { lagoons }\end{array}$ & Excellent/FG & 3 & Yes/? & Yes & 0 & 0 & \\
\hline 27. Lower San Juan River & Excellent/FG & 8 & Yes/2 & Yes & 0 & 0 & \\
\hline $\begin{array}{l}\text { 28. Upper San Juan River } \\
\text { and lower Lake } \\
\text { Nicaragua }\end{array}$ & $\begin{array}{l}\text { Some good areas } \\
\text { upstream from } \\
\text { rapids/FG }\end{array}$ & 3 & $?$ & No & 0 & 0 & \\
\hline Totals & & 198 & & & 4 & $41-49$ & $>52$ \\
\hline
\end{tabular}

${ }^{a}$ Numbers correspond to those in Fig. 1.

${ }^{\mathrm{b}} \mathrm{FG}=$ freshwater grasses, $\mathrm{SG}=$ seagrasses, $\mathrm{M}=$ mangrove.

${ }^{c}$ ? indicates uncertain reports or evidence.

${ }^{\mathrm{d}} \mathrm{H}=$ harpoon, $\mathrm{CN}=$ circle nets, $\mathrm{GN}=$ gill nets.

Secondly, manatees that inhabit these brackish ecosystems tend to rest in quiet, sheltered deep water during most of the day, moving to shallow waters to forage on submerged vegetation during the night, early morning and late afternoon; they may make lengthy daily movements from resting places to feeding grounds. Thirdly, manatees that live in brackish lagoons feed on submerged grasses (Sirigodium filiforme and Thalassia testudinum) and mangrove Rhizophora mangle leaves, whereas individuals inhabiting freshwater rivers feed mostly on true grasses (Oryza latifolia, Panicum maximum, Hymenachne amplexicaulis and Brachiaria sp.) and water hyacinth Eichhornia crassipes. Fourthly, manatee activity patterns are influenced by tides and, depending on the informant, they were reported to be more active when tides are changing or when they are rising.

\section{Threats and conservation issues}

Threats to manatees in Nicaragua are mostly from poaching or incidental trapping by nets. With the exception of Bluefields Bay, the intensity of boat traffic is low in 
all areas where manatees occur, and does not seem to be a significant cause of mortality. The few places with medium to high levels of water pollution are the Bluefields area and the San Juan River, where pesticides from neighboring Costa Rica drain into the basin. There is a potential threat to this river from proposed goldmining (AECO, 1996), which could shed toxins such as heavy metals and arsenic into the water (van Bennekom, 1996).

Although hunting of manatees is illegal in Nicaragua, poaching seems to be common. Local inhabitants talked about it openly, and this allowed me to assess the extent and intensity of poaching. There are three Miskito Indian communities (Bismuna Tara, Krukira and Haulover of Wounta) where 3-9 manatees are killed each year by hunters that include teenagers and middle-aged men (Table 1). This contrasts with other regions where poaching seems to be declining because most of the hunters are too old to continue with this difficult activity (Charnock-Wilson, 1968; O'Shea et al., 1988; Colmenero-R \& Zárate, 1990; Jiménez, 1999). Other Miskito Indian communities kill manatees occasionally or capture them incidentally in gill nets (Table 1). Depending on the village, manatee meat is either shared among the families or sold within the community. Manatees are also hunted by creole and garifona people in the Marshall Point, San Vicente, Raitipura and Kakabila communities of Pearl Bay, and meat is sold openly within the community or in the town of Pearl Lagoon. The Rama Indians of Rama Cay hunt manatees in Bluefields Bay and sell most of the meat in Bluefields. Various methods are used to capture manatees, but the most frequently used is stalking from a dugout canoe paddled by two people. When a manatee is seen it is struck with a harpoon lashed to a buoy, chased until it is exhausted, and then dragged close to the canoe and killed by hitting its snout with a club or axe.

Indigenous and local people were often unaware that killing manatees is illegal, as were some law enforcement officials in major towns. Similarly the use of gill nets in rivers and lagoons is widespread even though it is illegal. From the interviews I estimated that 41-49 manatees were killed in Nicaragua between January 1999 and the first three months of 2000 (Table 1), and that this offtake was similar in previous years. Manatees are used almost exclusively for meat, although the hides are sometimes used to make whips or as lobster bait. The local people do not have any strong curative traditions associated with manatee parts, in contrast to other regions where manatees are still used for their alleged healing powers (O'Shea et al., 1988; Reynolds \& Odell, 1992; Jiménez, 1999).

The Miskito Coast Biological Reserve, in north-east Nicaragua, and the Southeastern Nicaragua Biosphere
Reserve are the largest protected areas in the country with habitat suitable for manatees. The Miskito Coast Biological Reserve should legally protect all the coastal wetlands of the Miskito Coast, although no enforcement personnel are currently assigned to this area. The Miskito Indians interviewed were unaware of the existence of the protected area, and the three Miskito communities with the highest manatee hunting rates in the country are situated within the reserve. The Southeastern Nicaragua Biosphere Reserve was declared around pre-existing reserves in 1999, and by early 2000 nine rangers were assigned to the area. Most people living within the reserve knew that they were living in a protected area and that killing of manatees is forbidden. There are also some smaller protected areas, none of which have enforcement personnel. Conservation activities related to manatees have been almost non-existent in Nicaragua, with the exception of two educational campaigns led by the local NGO Mikupia in some of the Miskito lagoons in the mid 1990s, and by the Dutch projects DIPAL and PROCODEFOR around Pearl Bay and Bluefields Bay in 1998 and 1999 (Úbeda \& Weijerman, 1998). The impact of these two campaigns on the conservation of manatees seems to have been limited; one of the communities where Mikupia worked has the highest poaching rate in the country and, despite the visibility of posters that advise against the killing of manatees, people in Pearl Bay and Bluefields hunt them or buy their meat.

\section{Discussion}

Four facts indicate that Nicaragua may have one of the largest manatee populations in the Caribbean: 1) the species is found in almost every major watercourse, 2) people report seeing groups of up to 20 individuals, which implies the existence of high densities of manatees, 3) these reports of large groups were confirmed by Carr (1993) during his aerial surveys along the Miskito Coast, especially around Bismuna and Wounta lagoons, and 4) if more than 40 animals have been killed annually over the last decade then total numbers must be several times higher. However, although Nicaragua has the largest extent of habitat suitable for the manatee in the Caribbean and relatively low boat traffic and water pollution, the country has one of the lowest levels of protection for the species.

Although the species has been protected under a general hunting law with an indefinite closed season since 1972 (NRCA/UNEP, 1994), I found it impossible to find anyone in a relevant government agency who could provide information regarding the penalty for breaking this law. Most of the economical and political interests in Nicaragua are centred on the western, Pacific side, and government presence on the eastern, Caribbean 
side, is minimal, with an almost total absence of agents from the Ministry of Environment along this coast. Poaching of manatees seems to be implicitly accepted as an economically marginal activity. A manatee currently sells for more than 100 US\$ in Pearl Lagoon or Bluefields, which is more than a hunter's usual monthly income. The Miskito Coast Biological Reserve is a 'paper park' with no real protection for manatees; there is a lack of personnel, and no local awareness of the existence of the protected area. This is also the case for other protected areas in Pearl Bay, Bluefields Lagoon and the Punta Gorda River. The exception to this is the Southeastern Nicaragua Biosphere Reserve, especially on the San Juan and Indio rivers. This is the only region with excellent manatee habitat that has assigned personnel, and where people have some sense of living in a protected area and know that manatee hunting is prohibited and punishable by law. Although this region has less prime habitat and probably fewer manatees than the Miskito coast, it has the advantage of being adjacent to the Tortuguero Conservation area in Costa Rica, which has excellent manatee habitat and good enforcement (Jiménez, 1999, 2000).

Manatees can have a $7-10 \%$ annual population increase when conservation measures are enforced (Ackerman, 1995; Eberhardt \& O'Shea, 1995). Based on my estimate that $c .40$ manatees are being killed annually in Nicaragua a population of at least 400 individuals may therefore be necessary to assure long-term survival of the species under current conditions. Although there is no estimate of the number of manatees in Nicaragua, two facts indicate that the present hunting rate could be unsustainable in the long-term. Firstly, manatees have disappeared from some watercourses and became scarce in others. Secondly, most informants living in areas where manatees are still relatively common indicated that the species is not as common as it used to be. People have recently returned to their communities following the civil war of the 1980s, and the population of the region is increasing. In some lagoons most of the fishing banks have already been depleted, forcing people to look for alternative sources of protein or money. This is already the case in Bismuna Lagoon, where manatee hunting has apparently peaked over the last three years. If manatees are not actively protected in Nicaragua during the forthcoming decade the watercourses of the entire country could follow the fate of the Coco River, a place with relatively pristine habitat but no manatees.

\section{Acknowledgements}

The 2000 survey was funded by the $100 \%$ Fund of Fauna \& Flora International, Save the Manatee Club, Chiquita Brands, MARENA/CITES, Proyecto Corredor Biológico del Atlántico, IUCN, and Idea Wild. The Nicaragua Army and National Police, and the regional offices of MARENA assisted during the 2000 field season. The 1998 survey was funded by Amigos de la Tierra through Proyecto Corredor Biológico Fronterizo del Río San Juan and Idea Wild. Fabio Buitrago, Norwing Torres and Eddy Chacón assisted me and shared boat space during the 2000 field season, and so did Mariana Altrichter in 1998. The inhabitants of eastern Nicaragua kindly provided much of the information included in this paper. Chris Vaughan, Astrid Vargas, Thomas O'Shea and Bob Bonde reviewed the manuscript and provided valuable comments.

\section{References}

Ackerman, B.B. (1995) Aerial surveys of manatees: a summary and progress report. In Population Biology of the Florida Manatee (eds T.J. O'Shea, B.B. Ackerman \& H.F. Percival), pp. 13-33. Information and Technology Report I. US Department of Interior, National Biological Service, Washington DC, USA.

AECO (1996) Panorama de la minería a cielo abierto en Costa Rica. Unpublished report, San José, Costa Rica.

Baughman, J.L. (1946) Some early notices on American Manatees and the mode of their capture. Journal of Mammalogy, 27, 234-239.

Carr, T. (1993) The Manatees and Dolphins of the Miskito Coast Reserve, Nicaragua. Report prepared for the Marine Mammal Commission, Washington DC, USA.

Chacón, E. (2000) Estado de conservación del manatí en la zona sur de la Bahía de Bluefields. Lic. thesis, Escuela de Ecología, Universidad Centroamericana, Managua, Nicaragua.

Charnock-Wilson, J. (1968) The manatee in British Honduras. Oryx, 9, 293-294.

Colmenero-R, L.C. \& Zárate, B.E. (1990) Distribution, status and conservation of the West Indian Manatee in Quintana Roo, México. Biological Conservation, 52, 27-35.

Conzemius, E. (1932) Ethnographical Survey of the Miskito and Sumu Indians of Honduras and Nicaragua. Bureau of American Ethnology, Bulletin 106.

Eberhardt, L.L. \& O'Shea, T.J. (1995) Integration of manatee life-history data and population modeling. In Population Biology of the Florida Manatee (eds T.J. O'Shea, B.B. Ackerman \& H.F. Percival), pp. 269-279. Information and Technology Report I. US Department of Interior, National Biological Service, Washington DC, USA.

Hilton-Taylor, C. (compiler) (2000) 2000 IUCN Red List of Threatened Species. IUCN, Gland, Switzerland and Cambridge, UK.

Jiménez, I. (1998) Estado de conservación, ecología y cococimiento popular del manatí Trichechus manatus en el noreste de Costa Rica. Msc thesis, Programa Regional en Manejo de Vida Silvestre, Universidad Nacional, Heredia, Costa Rica.

Jiménez, I. (1999) Estado de conservación, ecología y conocimiento popular del manatí (Trichechus manatus, L.) en Costa Rica. Vida Silvestre Neotropical, 8, 18-30.

Jiménez, I. (2000) Los manaties del río San Juan y los canales de Tortuguero. Ecología y conservación. Amigos de la Tierra, San José, Costa Rica. 
Lefebvre, L.W., O'Shea, T.J., Rathbun, G.B. \& Best, R.C. (1989) Distribution, status, and biogeography of the West Indian manatee. In Biogeography of the West Indies: Past, Present and Future (ed. C.A. Woods), pp. 567-610. Sandhill Crane Press, Gainesville, Florida, USA.

Loveland, F.O. (1976) Tapirs and manatees: cosmological categories and social process among Rama Indians of eastern Nicaragua. In Frontier Adaptation in Lower Central America (eds M.W. Helms \& F.O. Lovel), pp. 67-82. Philadelphia Institute for the Study of Human Issues. Philadelphia, USA.

MARENA (1999) GIS Database of the Protected Areas of Nicaragua. Ministerio de Recursos Naturales, Managua, Nicaragua.

Nietschmann, B. (1972) Hunting and fishing focus among Moskito Indians, eastern Nicaragua. Human Ecology, 1, 41-67.

NRCA/UNEP (1994) Regional Management Plan for the West Indian manatee, Trichechus manatus. Natural Resources Conservation Authority, Kingston, Jamaica.

O'Donnell, D.J. (1981) Manatees and man in Central America. PhD thesis, University of California, Los Angeles, USA.

O'Shea, T.J., Correa-Viana, M., Ludlow, M.E. \& Robinson, J.G. (1988) Distribution, status and traditional significance of the West Indian Manatee Trichechus manatus in Venezuela. Biological Conservation, 46, 281-301.

O'Shea, T.J. \& Salisbury, C.A. (1991) Belize - a last stronghold for manatees in the Caribean. Oryx, 25, 156-164.

O'Shea, T.J., Ackerman, B.B. \& Percival, H.F. (1995) Population Biology of the Florida Manatee. Information and Technology Report I. US Department of Interior, National Biological Service, Washington DC, USA.
Phillips, R.C., Vadas, R.L. \& Ogden, N. (1982) The marine algae and seagrasses of the Moskito Bank, Nicaragua. Aquatic Botany, 13, 187-195.

Reynolds III, J.E. \& Odell, D.K. (1992) Manatees and Dugongs. Facts on File, New York, USA.

Úbeda, A. \& Weijerman, M. (1998) Informe sobre la situación del manatí en la cuenca de Laguna de Perlas, Región Autónoma del Atlántico Sur, Nicaragua. Report for Proyecto DIPAL II Laguna de Perlas, Nicaragua.

van Bennekom, S. (1996) Mining in Tropical Regions. The Netherlands Committee for IUCN, Amsterdam, Netherlands.

\section{Biographical sketch}

Ignacio Jiménez graduated in biology from the University of Valencia in 1992. In 1998 he obtained an M.Sc. in wildlife management and conservation with a thesis on the conservation and ecology of the West Indian manatee in northeastern Costa Rica. His main field of work is on endangered species recovery, and he has coordinated research and management projects in Costa Rica, Nicaragua, Madagascar and Spain. He is currently a member of Especies y Espacios Internacional, a Spanish organization that aims to conserve endangered species, and Fundación Salvemos al Manatí de Costa Rica, a local organization working on manatee conservation. 